\title{
Factors that influence the implementation of postharvest handling practices among fresh vegetable producers in selected states in Malaysia.
}

\begin{abstract}
This article examines the factors that influence the implementation of postharvest handling practices among fresh vegetable producers in selected states in Malaysia. The primary data were collected through a survey using a questionnaire with the total of 121 fresh vegetable producers. The study was conducted at Kedah, Pahang, Kelantan, and Selangor. The study utilizes the stratified sampling method. Both descriptive and inferential statistics were used to analyze the data. Factor analysis was carried out to identify the factors that influence the fresh vegetable producers to implement postharvest handling practices on their fresh produce. Based on the analysis, 6 factors were identified, namely, infrastructure, market availability, resources, government policy, knowledge, and attitude. The practice of postharvest handling on fresh produce can create value added to the product as well as increase the income of producers and enhance farm productivity.
\end{abstract}

Keyword: Postharvest handling practices; Postharvest losses; Fresh vegetable producers; Factor analysis. 